\title{
Research and Publication
}

\section{Requirements in University Libraries}

\begin{abstract}
A questionnaire survey of the ninety-four academic libraries holding membership in the Association of Research Libraries was conducted to determine the overall significance and ramifications of research and publication activity among academic librarians, with a major finding indicating that 15 percent of the libraries surveyed require librarians to publish.
\end{abstract}

T STATUS OF ACADEMIC LIBRARIANS has changed considerably over the past decade. As this status has changed, college and university librarians have experienced increased demands upon them to document their professional performance, notably in the area of scholarly research and publication. Arguments both for and against this heightened emphasis have been put forward in some detail, but those are not the concern of this investigation.

Rather, using librarians in the Association of Research Libraries (ARL) as a sample group, this study seeks to determine to what extent research and publication actually constitute a requirement for academic librarians, the inhibiting or promotional factors affecting this activity, and the ramifications that this issue holds not only for ARL librarians, but also for the field of academic librarianship itself.

\section{REVIEW OF THE LITERATURE}

A great deal has been written about the status of academic librarians, less about their overall research and publication activity, and almost nothing regarding the direct impact that research and publication have upon them as librarians, particularly with

Ronald Rayman and Frank Wm. Goudy are assistant professors, University Libraries, Western Illinois University, Macomb. The authors thank the Western Illinois University Libraries for the financial assistance that made this research possible. regard to questions of tenure and/or promotion.

Two studies of ARL librarians conducted during the late 1960 s revealed that, while verbal support was lent to the concept of research and publication for librarians, concrete assistance in the form of funding or released time was limited. Jesse and Mitchell found that support in the form of clerical assistance and photocopying allotments was sometimes available, but actual funding was scarce ${ }^{1}$ Kellam and Barker found tacit support for research and publication existed so long as library service was not compromised in any way. ${ }^{2}$ Both studies revealed that research and publication were viewed as a laudable "plus" but not as a requirement. Neither study broached the question of tenure, thereby implying that research and publication were not critical factors in tenure decisions.

A constricted job market, combined with the increased tendency to grant faculty status and tenure to academic librarians, altered this situation during the 1970s. More and more, scholarship on the part of academic librarians was demanded. ${ }^{3}$ At those institutions where librarians held faculty status, research and publication requirements tended to bring librarians into conformity with prevailing academic expectations for promotion and tenure consideration, a circumstance hindered by the fact that academic librarians traditionally have not been research oriented. ${ }^{4}$ )

Recent studies by Watson and by Davey 
and Andrews have suggested a possible alternative to this situation through the concept of "dual tracking" that would allow beginning librarians to gain badly needed onthe-job experience by delaying their entry into the normal tenure track by several years. ${ }^{5,6}$ This respite would permit them to gain valuable knowledge that could later be channeled into appropriate areas of research and publication.) This concept has received little attention in the field.

\section{METHODOLOGY}

A questionnaire containing twelve questions was mailed to the directors of the ninety-four academic libraries that hold membership in the ARL. Each questionnaire was accompanied by a self-addressed, postage-paid return envelope to facilitate replies and to help ensure a favorable return rate. Whether due to the ease of replying, a keen interest in the questionnaire topic, or both, one-half of the questionnaires were returned within seven working days from the original date of mailing, and sixty-eight replies (72 percent of the entire sample) were eventually returned.

The opening four questions requested data regarding the formal status of librarians at each institution, their eligibility for tenure, and a determination whether research and publication was or was not mandatory. The next five questions sought to measure various types and amounts of support provided by the institution or individual library to promote research and publication. The final three questions were relevant only where librarians were required to publish for tenure and/or promotion consideration, and those dealt with identifying appropriate publication mediums and established criteria to measure publication activity.

\section{FINDINGS}

Table 1 summarizes the findings from the survey. For the initial question pertaining to status, twenty-four libraries ( 35 percent) reported that librarians held faculty status; twenty-eight (41 percent) reported academic status; and sixteen ( 24 percent) indicated a status of "other."

Academic status denotes a separate professional classification that is neither civil service nor administrative and yet does not meet the standards for faculty status including corresponding rank, promotion, tenure, and compensation as detailed by the ACRL "Standards for Faculty Status for College and University Librarians" adopted in June 1971. For the third group, "other," most institutions listed the librarians' status as an administrative classification within their individual schools. ${ }^{7}$

\section{Tenure}

On the question of tenure, librarians at thirty-nine institutions were eligible for tenure, while twenty-nine indicated that librarians were not eligible for tenure. ${ }^{8}$

Hardly surprising was the fact that at all twenty-four institutions where librarians held faculty status they were eligible for tenure as well. For librarians holding academic status, one-half were eligible and one-half were not.

At the opposite end of the spectrum were those libraries that had noted an "other" status. A single library out of that entire group of sixteen reported that librarians were eligible for tenure.

These findings reveal a clear breakdown on the question of tenure for librarians. Faculty status is the single most important factor in determining tenure eligibility, while those librarians holding academic or "other" status experienced a descending probability of eligibility for tenure.

\section{Publishing Activity}

The most important question raised by the questionnaire related to publication activity. Unfortunately, previous studies on this issue of vital significance to academic librarians, particularly in the realm of mandatory research and publication, are nonexistent. This precludes comparative analysis with earlier findings, but it is hoped that the present study will provide a needed benchmark for future investigations and analyses.

Faculty status and tenure eligibility were key elements in establishing publication as a requirement for librarians. Of the entire group of responding libraries, only ten replied that librarians were required to publish, all of which were institutions where librarians held faculty status and were eligible for tenure. Librarians were encouraged 
TABLE 1

Publication ReQuirements in ARL Libraries

\begin{tabular}{|c|c|c|c|c|c|c|c|c|}
\hline \multirow[t]{2}{*}{ Category } & \multicolumn{2}{|c|}{$\begin{array}{c}\text { All } \\
\text { Responses } \\
(\mathbf{N}=68)\end{array}$} & \multicolumn{2}{|c|}{$\begin{array}{c}\text { Faculty } \\
\text { Status } \\
(\mathrm{N}=24)\end{array}$} & \multicolumn{2}{|c|}{$\begin{array}{c}\text { Academic } \\
\text { Status } \\
(\mathbf{N}=28)\end{array}$} & \multicolumn{2}{|c|}{$\begin{array}{c}\text { "Other" } \\
\text { Status } \\
(\mathbf{N}=16)\end{array}$} \\
\hline & & & & & & & & \\
\hline \multicolumn{9}{|l|}{ Professional } \\
\hline Classification: & 68 & 100 & 24 & 35 & 28 & 41 & 16 & 24 \\
\hline \multicolumn{9}{|l|}{ Tenure Granted: } \\
\hline Yes & 39 & 57 & 24 & 100 & 14 & 50 & 1 & 6 \\
\hline No & 29 & 43 & 0 & 0 & 14 & 50 & 15 & 94 \\
\hline \multicolumn{9}{|l|}{ Publication Requirements: } \\
\hline Required & 10 & 15 & 10 & 42 & 0 & 0 & 0 & 0 \\
\hline Encouraged; not required & 41 & 60 & 13 & 54 & 20 & 71 & 8 & 50 \\
\hline Not encouraged & 17 & 25 & 1 & 4 & 8 & 29 & 8 & 50 \\
\hline \multicolumn{9}{|l|}{ Publication Required for: } \\
\hline Promotion only & 1 & 10 & 1 & 10 & - & - & - & - \\
\hline Tenure only & 0 & 0 & 0 & 0 & - & - & - & - \\
\hline Promotion and tenure & 9 & 90 & 9 & 90 & - & - & - & - \\
\hline \multicolumn{9}{|l|}{ Required Publication in: } \\
\hline Librarianship only & 2 & 20 & 2 & 20 & - & - & - & - \\
\hline All disciplines & 8 & 80 & 8 & 80 & - & - & - & - \\
\hline \multicolumn{9}{|l|}{ Publication Released Time: } \\
\hline Specific released time & 7 & 10 & 4 & 17 & 3 & 11 & 0 & 0 \\
\hline Apply for released time & 28 & 41 & 13 & 54 & 9 & 32 & 6 & 37 \\
\hline No release time & 33 & 49 & 7 & 29 & 16 & 57 & 10 & 63 \\
\hline \multicolumn{9}{|l|}{ Funding for Research: } \\
\hline Within library & 18 & 23 & 11 & 33 & 2 & 7 & 5 & 29 \\
\hline From university & 40 & 51 & 20 & 61 & 16 & 57 & 4 & 24 \\
\hline Not available & 20 & 26 & 2 & 6 & 10 & 36 & 8 & 47 \\
\hline \multicolumn{9}{|l|}{ Library Research Committee: } \\
\hline Yes & 20 & 31 & 16 & 67 & 2 & 7 & 2 & 12 \\
\hline No & 45 & 69 & 8 & 33 & 23 & 93 & 14 & 88 \\
\hline
\end{tabular}

to publish, but not required to do so, at forty-one institutions.

Librarians were not required to publish, and publication received no special emphasis at seventeen libraries, eight each at academic and "other" status libraries, and surprisingly at one library with both faculty status and tenure eligibility.

These responses indicated that, for the most part, academic librarians are still not required to publish, although taken in the aggregate, fifty-one libraries either require or encourage publication. Again, the lack of comparative data is a keenly felt deficiency here. A similar study five years hence might produce significantly different results as publication becomes more commonplace for academic librarians.

Several other interesting facets of the publication issue were noted. Of the ten libraries reporting that publication was mandatory, nine stated that it was necessary for tenure and promotion, while one library noted that publication was necessary for promotion only. At least four libraries that encouraged but did not require publication affirmed that publication was a definite asset in securing favorable tenure and/or promotion decisions. Only two of the ten libraries requiring publication responded that publication had to be related to the field of librarianship; the other eight stated that publication could relate to any accepted academic discipline. ${ }^{y}$

\section{Released Time}

These basic questions pertained to research and publication as a requirement and not to basic support provided to promote that same activity. The specific question of released time drew nearly identical responses as thirty-five libraries responded that some form of released time was available, while thirty-three indicated that no released time whatsoever was provided.

For those indicating that released time was available, three noted that no record was maintained of hours worked or devoted to research, one indicated a thirty-hour workweek, two responded that four hours of 
a forty-hour workweek could be devoted to research, and one library reported that four weeks of research time were granted annually to librarians. Allotments of specific released time were thinly distributed over the three status designations (four faculty status, three academic status, and none for "other").

Much more prevalent was released time that one applied for on an individual basis, normally to the library director. ${ }^{10}$ Twentyeight libraries (41 percent of the entire responding group) indicated that librarians could apply for and receive varying amounts of released time to pursue research activities. This category was more evenly distributed over the three status designations than were the majority of the findings of this study. Thirteen libraries with faculty status fell into this group, as did nine from the academic group and six from the other group.

Unfortunately for the field of academic librarianship, thirty-three libraries reported that no released time was provided under any circumstances, either set aside time or on an application basis. It hardly came as a surprise then that where librarians were only encouraged to publish only four allotted specific released time, sixteen allowed applied-for released time, and twenty-one permitted no released time.

It was a revelation to discover, however, that of those ten libraries at which librarians were required to publish, only three allowed specific released time, six made provision for it on an application basis, and one library made no provision for released time to pursue research and publication activities.

\section{Funding}

Closely allied to the released time question was one dealing with the availability of funding to support research and publication efforts. More than one response was permitted if funding was available from both the institution and the library, so the total number of responses (seventy-eight) exceeded the total number of questionnaires returned. Funding within the individual libraries was available in eighteen instances, and from the institution in forty instances; twenty libraries reported that no type of funding was available from either source.

Librarians at the twenty-four institutions with faculty status revealed far better opportunities of securing funding than those with either academic or "other" status. In only two cases was no source of funding available, compared to ten of the total academic status group, and eight of the total "other" status group.

It should also be pointed out that for those ten institutions that required librarians to publish all reported that some type of funding was available: in three-fourths of the group, librarians could seek financial support from both the library and the parent institution. For those encouraged but not required to publish, funding sources were more limited, but still significant (seven within the library, twenty-eight from the institution, and ten reporting no funding available). Only one-half of the "other" group received any funding.

\section{Research Committees}

Beyond the fundamental issues of released time and funding, a question was asked to determine to what extent the libraries surveyed organized and maintained specific library committees to promote and facilitate research and publication. ${ }^{11}$ In response to this question, only twenty libraries noted the existence of such a committee. Almost two-thirds of the respondents stated that no such committee existed at their library, and three libraries did not respond to the question. Those libraries with faculty status were the most likely to have a research committee, with sixteen reporting such a committee.

Those groups in the academic and "other" status groups lagged far behind in this category as less than 10 percent of this combined group supported a research committee. Two-thirds of those required to publish had a committee (six out of the nine respondents), while only twelve out of fortyone libraries in the group encouraged to publish and a mere two libraries in the group not encouraged to publish supported a research committee.

\section{Acceptable Publications}

Finally, libraries that required librarians to publish were asked to identify acceptable 
publications. All ten libraries in this category indicated that books, journal articles, and chapters in a book or festschriften were legitimate publication outlets. The other major forms of publication indicated were conference papers (nine), book reviews (six), and in-house publications (three). In this same vein, the libraries were asked if quantified standards had been established to measure publication activity, and all ten gave a negative response.

\section{CONCLUSIONS}

This study shows that, regardless of status, 15 percent of all librarians in the Association of Research Libraries are required to publish. All in this required group have faculty status and are eligible for tenure. Since the cited studies of Jesse and Mitchell and also Kellam and Barker from the late 1960 s made no mention that research and publication were mandatory at any of the libraries surveyed or were crucial factors in tenure decisions, by implication, then, the impetus for required research and publication is a phenomenon of the past decade.

This shift is clearly on the increase. Several questionnaire respondents provided additional comments that indicated that research and publication had recently be- come, or shortly would become, mandatory at their institutions, thus marking an even more distinct break from past practice whereby academic librarians were under no compulsion to engage in scholarly research and publication activities.

Unfortunately, research and publication by academic librarians are not well supported, even where mandatory. Structured workweeks, combined with relatively stringent opportunities for released time, foster a climate where the pursuit of scholarly research and publication is extremely difficult, a circumstance compounded to a lesser, but still significant, degree by inadequate funding.

Librarians at institutions with either academic or "other" status have not yet been required to perform scholarly research and publish, and this is not likely to change. Those librarians holding faculty status and those who may acquire faculty status at some future date are unquestionably the group most likely to be affected by increased standards and requirements. For all academic librarians required to perform scholarly research and publication, or those not required but with the creative and scholarly urge to do so, the task will continue to be a difficult one.

\section{REFERENCES}

1. William Jesse and A. E. Mitchell, "Professional Staff Opportunities for Study and Research," College \& Research Libraries 29:87-100 (March 1968).

2. W. Porter Kellam and Dale L. Barker, "Activities and Opportunities of University Librarians for Full Participation in the Educational Enterprise," College \& Research Libraries 29:197-99 (May 1968).

3. Rao Aluri and Jeffrey W. St. Clair, "Academic Reference Librarians: An Endangered Species?" Journal of Academic Librarianship 4:83 (May 1978); Beatrice Hight, ed., Criteria for Promotion and Tenure of Librarians in Zimmerman, Parish, and Fine Arts Libraries of the University of New Mexico, Albuquerque, New Mexico (New Mexico University: Zimmerman Library, 1973), ERIC ED 080 124; and Daniel O'Connor and Phyllis Van Orden, "Getting into Print," College \& Research Libraries 39:389 (Sept. 1978).

4. Susan L. Miller and others, "To Be or Not to
Be: An Academic Library Research Committee," Journal of Academic Librarianship 2:23 (March 1976).

5. Paula De Simone Watson, "Publication Activity among Academic Librarians," College $b$ Research Libraries 38:382-83 (Sept. 1977).

6. Nancy Davey and Theodora Andrews, "Implications of Faculty Status for University Librarians, with Special Attention to Tenure," Journal of Academic Librarianship 4:73-74 (May 1978).

7. "Standards for Faculty Status for College and University Librarians," College \& Research Libraries News 33:210-12 (Sept. 1972). See also Anis Kurshid and Glenora Edwards Russell, "Academic Status of Librarians," in Encyclopedia of Library and Information Science 1:39-45 (New York: Marcel Dekker, 1968).

8. By comparison, a study completed in 1977 showed that for non-ARL, four-year institutions with graduate programs, 60 percent of all librarians surveyed were eligible for ten- 
ure. See Anne Marie Allison, Factors Affecting Administration in United States Academic Libraries during the Period 1971-1975, University of Illinois Graduate School of Library Science Occasional Papers, no.138 (Urbana: Graduate School of Library Science, University of Illinois, 1979), p.22.

9. By contrast, Jesse and Mitchell reported a 50-50 split (for sixteen responses) on this same question. Jesse and Mitchell, "Professional Staff Opportunities," p.90.
10. This finding was corroborated by that of a study which reported that the granting of released time normally fell "directly within the province of the director of libraries." Virgil F. Massman, Faculty Status for Librarians (Metuchen, N.J.: Scarecrow, 1972), p.178. Jesse and Mitchell ("Professional Staff Opportunities," p.100) also emphasized the director's role. See also Miller, "To Be or Not to Be," p.20-24.

11. Miller, "To Be or Not to Be," p.20-24. 